\title{
Physiological Responses and Antioxidant of Wheat Cultivars in PGR -Mediated Alleviation of Drought Stress
}

Dehghanzadeh $\mathrm{H}$ and Adavi $\mathrm{Z}^{*}$

Department of Agriculture, Payame Noor University, Iran

*Corresponding author: Zohrab Adavi, Department of Agriculture, Payame Noor University, Tehran, Iran

Received: March 11, 2021; Accepted: April 02, 2021;

Published: April 09, 2021

\begin{abstract}
Drought is one of the most important abiotic stresses and factors limiting the successful production of plant products worldwide and has adverse effects on plant growth and other metabolic processes. The role of exogenous individual or combined application of Silicon (Si) and Cycocel (CCC) (control, $3.6 \mathrm{gL}^{-1} \mathrm{Si}$, $210 \mathrm{mgL}^{-1} \mathrm{CCC}$, and $3.6 \mathrm{gL}^{-1} \mathrm{Si}+210 \mathrm{mgL}^{-1} \mathrm{CCC}$ ) on grain yield and some key physiological characteristics of wheat (Triticum aestivum L.) cv. Gascogen (drought-sensitive) and Aflak (drought-tolerant) was investigated under field water-stress conditions ( $100 \%$ and $40 \%$ field capacity). Drought stress caused a considerable reduction in biological yield, yield and yield components, relative water content and leaf water potential of both cultivars. Application of Si and CCC effectively improved these parameters in water-deficit treatments. Moreover, water-limited conditions markedly promoted the activities of key antioxidant enzymes including peroxidase, ascorbate peroxidase, catalase and superoxide dismutase as well as the levels of Malondialdehyde (MDA) and hydrogen peroxide $\left(\mathrm{H}_{2} \mathrm{O}_{2}\right)$, while enhancing the accumulation of soluble sugars, potassium, magnesium and calcium in leaf tissues. Application of Si and CCC further enhanced the activities of the key antioxidant enzymes and accumulation of osmolytes, and decreased the levels of $\mathrm{H}_{2} \mathrm{O}_{2}$ and MDA in drought stressed plants; the positive effects of $\mathrm{Si}$ were greatest when it was applied with CCC. Synergistic effects of $\mathrm{Si}+\mathrm{CCC}$ application on yield and physiological parameters were apparent compared with Si or CCC applied separately water-stress alleviation and yield improvement in the wheat cultivars by $\mathrm{Si}$ and CCC application was attributable to partly improved osmotic adjustment and antioxidant activity as well as to more favorable water status under stress conditions. Overall, Si and CCC application proved to have great potential in promoting grain yield of wheat in drought-prone areas.
\end{abstract}

Keywords: Drought; Membrane stability; Oxidative stress; Plant growth regulator wheat

\section{Introduction}

Wheat is a major staple food crop in the world. Increasing grain yield and improving quality are of great importance for the increasing human population [1]. Although all abiotic stresses adversely affect the wheat growth and production, water scarcity imposes the most severe effects on this crop [2]. Water scarcity adversely affects all phases of growth, most strikingly noted at the reproductive phase and grain filling, leading to fewer grains and smaller grain size in cereal crops including wheat. Impairment of assimilate partitioning and of activities of vital enzymes taking part in the synthetic processes of key carbohydrates including starch and sucrose reduces grain filling $[3,4]$. Drought stress is also believed to affect the uptake, transport and accumulation of key inorganic nutrients in plants [5].

According to Rao et al. [6] and Zhang et al. [7], soils are teemed with Silicon (Si). Si occurs abundantly in soils, but in the field of plant growth the other inorganic elements such as Nitrogen $(\mathrm{N})$, Potassium (K), Phosphorus (P), Calcium (Ca) and Magnesium for plant growth $(\mathrm{Mg})$ are more important than Si. However, Si plays an effective role in plants under stressful conditions [8-10]. E.g. Si is believed to be effective in alleviating the detrimental effects of Salinity, drought, high temperature and heavy metals on plants [10-12]. Moreover, researches shows that $\mathrm{Si}$ entails useful effects in plants under waterdeficit treatments, with respect to drought-induced regulation of metabolic processes and water relations $[7,13,14]$.

However, the mechanism by which Si can effectively alleviate drought-induced harmful effects remains unknown. Various Plant Growth Regulators (PGRs) are currently used to achieve enhanced growth and production of different crops worldwide [15-17]. Of several PGRs, Cycocel (CCC) is believed to be very effective in masking the adverse effects of different abiotic and biotic stresses on crops as well as being an essential component of the signaltransduction pathways operating in plants exposed to environmental cues including drought stress [18]. Ashraf and Foolad [19] reported that CCC also has a crucial function in the mechanism of plant water stress tolerance. Exogenously applied CCC is believed to affect absorption and transport of nutrients [20], stomata regulation [21], growth and photosynthetic rate [22], chlorophyll synthesis [23] and transpiration [21].

Besides, both Si $[14,24]$ and CCC $[25,26]$ can promote the antioxidative defenses systems, both enzymatic and non-enzymatic, 
and consequently leads to reduce damage from Reactive Oxygen Species (ROS) caused by stresses. Using Si [27] and CCC [23] also raises synthesis of osmolytes, enhancing plant tolerance versus stresses. Researchers $[28,29]$ showed the beneficial role of osmolytes in osmoregulation. Szabados and Savoure [30] reported that the piling up of osmolytes in leaves might be effective in one or more of the above-mentioned processes and water-deficit tolerance.

Although, it has been shown that exogenous supplementation of Si or CCC can effectively promote the endurance of plants against a variety of stresses $[7,18,25,31]$, the literature has little information on the role of Si and CCC applied in combination in alleviating droughtinduced injurious effects on plants. Therefore, in the present study, we appraised the effects of exogenous Si and CCC applied individually or in combination on wheat growth and grain yield under water-deficit conditions.

\section{Materials and Methods}

\section{Plant materials and growth conditions}

Two wheat cultivars, Gascogen (drought-sensitive) and Aflak (drought-tolerant), were selected. Seeds of uniform size of both cultivars were sown in a field at the Research Farm of the College of Agriculture (altitude $1180 \mathrm{~m}$ a.m.s.l.), Esfahan, Iran, during the 2018-19 growing season. The crop was irrigated with good-quality irrigation water. The soil texture is loam, $\mathrm{pH}\left(\mathrm{H}_{2} \mathrm{O}\right) 7.7$ and electrical conductivity (EC) $2.55 \mathrm{dSm}^{-1}$.

\section{Experimental design and treatments}

The experiment was set up in a split-split-plot complete randomized block design with three replicates. Watering treatments (100\% and 40\% Field Capacity (FC)) were considered as main plots; foliar application of Si and CCC (control (nil), 3.6gL $\mathrm{gL}^{-1} \mathrm{Si}, 210 \mathrm{mgL}^{-1}$ CCC, and $3.6 \mathrm{gL}^{-1} \mathrm{Si}+210 \mathrm{mgL}^{-1} \mathrm{CCC}$ ) as sub-subplots; and the two wheat cultivars as sub-subplots. The seeds were hand-sown (150kgha$\left.{ }^{1}\right)$ during the first week of November in 2018. Each plot was $3 \mathrm{~m}$ wide and $2 \mathrm{~m}$ long. The soil was fertilized with $150 \mathrm{kgha}^{-1}$ of urea before sowing, and at mid-tillering and anthesis stages. Until the anthesis stage, all plots were irrigated to maintain $100 \%$ FC. From anthesis to ripening, water-stress treatment was initiated to maintain $40 \% \mathrm{FC}$, while the control plots were maintained at $100 \%$ FC. Silicon and CCC were sprayed onto the leaves of the appropriate plants at tillering and anthesis. These chemicals were sprayed for three consecutive days to ensure their uptake by the plants.

\section{Measurements}

All measurements based on fresh plant samples were done before the grain-filling stage. The fully expanded flag leaves were used for all biochemical analysis. Measurements included Relative Water Content (RWC) [32], soluble sugars [33] and soluble proteins [34]; activities of Peroxidase (POD) [35], Ascorbate Peroxidase (APX) [36], Catalase (CAT) [37] and Superoxide Dismutase (SOD) [38]; levels of hydrogen peroxide $\left(\mathrm{H}_{2} \mathrm{O}_{2}\right)$ [39] and Malondialdehyde (MDA) [40]; concentrations of $\mathrm{Ca}, \mathrm{K}$ and $\mathrm{Mg}$ by flame photometer (model 410; Corning Inc., Corning, NY, USA); and leaf water potential ( $\Psi \mathrm{m})$ (PMS Instrument Company, Albany, OR, USA). At maturity, grain yield, number of grains per spike, 1000 grain weight and harvest index were measured.

\section{Statistical analysis}

Analysis of variance was performed on data for each parameter by using SAS version 9.2 software (SAS Institute, Cary, NC, USA). Significant differences among mean values were compared using Duncan's multiple range test $(\mathrm{P} \leq 0.05)$.

\section{Results}

\section{Yield and yield components}

Water stress (40\% FC) significantly reduced grain number per spike by $24.65 \%$ in cv. Aflak and $38.77 \%$ in cv. Gascogen. The negative impact of water stress on number of grains per spike was alleviated by application of $\mathrm{Si}$ and CCC. Under water stress, foliar application of $\mathrm{Si}$, CCC and $\mathrm{Si}+\mathrm{CCC}$ caused an increase of $11.32 \%$, $11.64 \%$ and $18.19 \%$, respectively, in grain number per spike in $\mathrm{cv}$. Aflak, and $8.44 \%, 10.91 \%$ and $13.97 \%$ in cv. Gascogen (Table 1). Furthermore, in both wheat cultivars, 1000 grain weight decreased significantly under water stress. The drought-tolerant cultivar Aflak had higher 1000-grain weight than drought-sensitive Gascogen under water stress (Table 1). The decline in 1000-grain weight was considerably less in plants supplied with $\mathrm{Si}, \mathrm{CCC}$ or $\mathrm{Si}+\mathrm{CCC}$ than that when these treatments were not applied. Therefore, foliar application of these treatments can significantly improve 1000-grain weight under field water-deficit conditions; maximum benefit was recorded with Si + CCC when applied under water-stress conditions to $\mathrm{cv}$. Aflak, increasing 1000-grain weight by $22.90 \%$ (Table 1). Grain yield decreased significantly under water-stress conditions, by $35.55 \%$ in drought-tolerant cv. Aflak and $63.00 \%$ in droughtsensitive cv. Gascogen. However, foliar application of CCC, Si and $\mathrm{Si}+\mathrm{CCC}$ caused a significant increase in grain yield under waterlimited conditions. The effect of $\mathrm{Si}+\mathrm{CCC}$ was greater than of Si or CCC applied separately (Table 1 ). With applications of Si, CCC and $\mathrm{Si}+\mathrm{CCC}$, grain yield was $18.31 \%, 19.71 \%$ and $31.96 \%$ higher, respectively, for cv. Aflak, and $11.03 \%, 18.61 \%$ and $23.36 \%$ higher for cv. Gascogen than with no foliar application under water stress (Table 1). In both cultivars, the biological yield decreased significantly under water-stress conditions; however, Si and CCC treated plants had higher biological yield than untreated plants under water stress alone. The effect of $\mathrm{Si}+\mathrm{CCC}$ application on biological yield was greater than of Si or CCC applied separately (Table 1). Water stress decreased harvest index of drought-sensitive Gascogen only. Foliar application of Si + CCC significantly promoted harvest index of both wheat varieties under water-limited conditions (Table 1).

\section{Organic substances (soluble sugars and soluble proteins) and inorganic ions}

Soluble sugar concentration in the flag leaf increased significantly under water-stress conditions, by $19.09 \%$ in cv. Gascogen and $43.83 \%$ in cv. Aflak (Table 2). Plants treated with Si and CCC had significantly higher soluble sugar content than untreated plants under water stress alone. The influence of $\mathrm{Si}+\mathrm{CCC}$ on soluble sugars in plants under water stress tended to be greater than of Si or CCC applied separately. The response of cultivars to $\mathrm{Si}$ and CCC varied significantly, with cv. Aflak more responsive; in Si, CCC and Si + CCC treatments and under water stress, soluble sugar content was $21.75 \%, 15.20 \%$ and $29.57 \%$ higher, respectively, in cv. Aflak, and $13.70 \%, 15.71 \%$ and $21.10 \%$ higher in cv. Gascogen than with no foliar application (Table 2). In both cultivars the levels of soluble proteins decreased markedly 
Table 1: Influence of separate or combined application of Silicon (Si, 3.6 $\left.\mathrm{gL}^{-1}\right)$ and Cycocel $\left(\mathrm{CCC}, 210 \mathrm{mgL}^{-1}\right)$ on yield, yield components, biological yield and harvest index of two wheat cultivars (Gascogen and Aflak) under field water-stress and non-stress conditions.

\begin{tabular}{|c|c|c|c|c|c|c|c|c|c|c|c|}
\hline \multirow{2}{*}{ Irrigation treatment } & \multirow{2}{*}{ Chemical treatment } & \multicolumn{2}{|c|}{ No. of grains per spike } & \multicolumn{2}{|c|}{1000 -grain weight $(\mathrm{g})$} & \multicolumn{2}{|c|}{ Grain yield $\left(\mathrm{gm}^{-2}\right)$} & \multicolumn{2}{|c|}{ Biological yield $\left(\mathrm{gm}^{-2}\right)$} & \multicolumn{2}{|c|}{ Harvest index } \\
\hline & & Gascogen & Aflak & Gascogen & Aflak & Gascogen & Aflak & Gascogen & Aflak & Gascogen & Aflak \\
\hline \multirow{4}{*}{$100 \%$ field capacity } & 0 & $41.01^{\mathrm{b}}$ & $40.56^{b}$ & $42.00^{\mathrm{a}}$ & $42.00^{\mathrm{a}}$ & $570.00^{a}$ & $570.87^{a}$ & $1353.62^{\mathrm{a}}$ & $1300.52^{b}$ & $42.18^{b}$ & $43.53^{b}$ \\
\hline & $\mathrm{Si}$ & $41.61^{\mathrm{b}}$ & $43.12^{\mathrm{a}}$ & $42.32^{\mathrm{a}}$ & $42.32^{\mathrm{b}}$ & $570.65^{a}$ & $570.32^{a}$ & $1342.00^{\mathrm{a}}$ & $1310.23^{\mathrm{ab}}$ & $42.45^{\mathrm{b}}$ & $43.71^{\mathrm{b}}$ \\
\hline & $\mathrm{CCC}$ & $41.54^{b}$ & $41.32^{b}$ & $42.81^{\mathrm{a}}$ & $42.81^{\mathrm{a}}$ & $580.23^{a}$ & $578.32^{\mathrm{a}}$ & $1336.23^{a}$ & $1315.02^{\mathrm{ab}}$ & $43.50^{\mathrm{b}}$ & $43.58^{b}$ \\
\hline & $\mathrm{Si}+\mathrm{CCC}$ & $43.52^{\mathrm{a}}$ & $43.63^{a}$ & $43.15^{a}$ & $43.15^{b}$ & $584.47^{\mathrm{a}}$ & $582.23^{a}$ & $1380.23^{a}$ & $1364.02^{\mathrm{a}}$ & $42.38^{b}$ & $42.30^{b}$ \\
\hline \multirow{4}{*}{$40 \%$ field capacity } & 0 & $25.11^{\mathrm{g}}$ & $30.56^{e}$ & $22.52^{f}$ & $22.52^{\mathrm{d}}$ & $210.87^{g}$ & $367.87^{d}$ & $600.68^{g}$ & $835.32^{\mathrm{e}}$ & $35.00^{d}$ & $43.19^{b}$ \\
\hline & $\mathrm{Si}$ & $27.23^{f}$ & $34.02^{\mathrm{d}}$ & $25.05^{e}$ & $25.05^{c}$ & $234.15^{f}$ & $435.23^{c}$ & $650.10^{f}$ & $970.50^{d}$ & $35.84^{d}$ & $44.23^{\mathrm{ab}}$ \\
\hline & $\mathrm{CCC}$ & $27.85^{\dagger}$ & $34.12^{\mathrm{d}}$ & $25.00^{e}$ & $25.00^{c}$ & $250.12^{\mathrm{e}}$ & $440.40^{c}$ & $653.14^{e}$ & $970.25^{d}$ & $38.02^{\mathrm{c}}$ & $45.12^{\mathrm{ab}}$ \\
\hline & $\mathrm{Si}+\mathrm{CCC}$ & $28.62^{f}$ & $35.12^{c}$ & $26.01^{\mathrm{e}}$ & $26.01^{\mathrm{b}}$ & $260.13^{e}$ & $485.45^{b}$ & $668.12^{\mathrm{e}}$ & $1000.88^{c}$ & $38.45^{c}$ & $48.12^{\mathrm{a}}$ \\
\hline
\end{tabular}

For each parameter, means followed by the same letter are not significantly different at $\mathrm{P}=0.05$.

Table 2: Influence of separate or combined application of Silicon $\left(\mathrm{Si}, 3.6 \mathrm{gL}^{-1}\right)$ and Cycocel $\left(\mathrm{CCC}, 210 \mathrm{mgL}^{-1}\right)$ of soluble sugars, soluble proteins and mineral nutrients in the leaves of two wheat cultivars (Gascogen and Aflak) under field water-stress and non-stress conditions Measures of sugars and minerals by dry weight, protein by fresh weight.

\begin{tabular}{|c|c|c|c|c|c|c|c|c|c|c|c|}
\hline \multirow{2}{*}{ Irrigation treatment } & \multirow{2}{*}{ Chemical treatment } & \multicolumn{2}{|c|}{ Soluble sugars } & \multicolumn{2}{|c|}{ Soluble proteins } & \multicolumn{2}{|c|}{ Potassium } & \multicolumn{2}{|c|}{ Magnesium } & \multicolumn{2}{|c|}{ Calcium } \\
\hline & & Gascogen & Aflak & Gascogen & Aflak & Gascogen & Aflak & Gascogen & Aflak & Gascogen & Aflak \\
\hline \multirow{4}{*}{$100 \% \mathrm{FC}$} & 0 & $43.00^{9}$ & $43.12^{\mathrm{g}}$ & $16.50^{\mathrm{b}}$ & $15.50^{\mathrm{bc}}$ & $48.63^{h}$ & $47.08^{\mathrm{hi}}$ & $2.30^{\mathrm{e}}$ & $2.31^{\mathrm{e}}$ & $8.33^{d}$ & $7.25^{a}$ \\
\hline & $\mathrm{Si}$ & $46.32^{\mathrm{fg}}$ & $47.32^{f}$ & $15.85^{\mathrm{bc}}$ & $15.32^{\mathrm{bc}}$ & $48.52^{\mathrm{h}}$ & $48.10^{\mathrm{h}}$ & $2.31^{\mathrm{e}}$ & $2.28^{e}$ & $8.10^{d}$ & $7.26^{\mathrm{b}}$ \\
\hline & $\mathrm{CCC}$ & $47.00^{f}$ & $47.86^{f}$ & $16.00^{\mathrm{b}}$ & $15.69^{b c}$ & $52.00^{g h}$ & $52.01^{\mathrm{gh}}$ & $2.30^{\mathrm{e}}$ & $2.29^{e}$ & $8.21^{d}$ & $7.15^{a}$ \\
\hline & $\mathrm{Si}+\mathrm{CCC}$ & $47.08^{f}$ & $50.00^{f}$ & $17.65^{\mathrm{a}}$ & $18.23^{\mathrm{a}}$ & $53.00^{\mathrm{g}}$ & $52.11^{\mathrm{gh}}$ & $2.29^{e}$ & $2.31^{\mathrm{e}}$ & $8.15^{d}$ & $7.28^{b}$ \\
\hline \multirow{4}{*}{$40 \% \mathrm{FC}$} & 0 & $51.21^{f}$ & $62.02^{\mathrm{d}}$ & $10.52^{f}$ & $12.36^{\mathrm{e}}$ & $56.23^{g}$ & $65.00^{\mathrm{e}}$ & $2.88^{d}$ & $4.07^{b}$ & $9.36^{c}$ & $11.76^{a}$ \\
\hline & $\mathrm{Si}$ & $58.23^{\mathrm{de}}$ & $75.51^{\mathrm{ab}}$ & $14.02^{\mathrm{d}}$ & $14.36^{\mathrm{d}}$ & $61.85^{f}$ & $73.10^{c}$ & $2.85^{d}$ & $4.10^{b}$ & $9.45^{c}$ & $12.95^{\mathrm{a}}$ \\
\hline & $\mathrm{CCC}$ & $59.26^{d}$ & $71.45^{\mathrm{bc}}$ & $14.00^{d}$ & $14.32^{\mathrm{d}}$ & $63.15^{d}$ & $78.00^{a}$ & $3.02^{c}$ & $4.65^{a}$ & $9.27^{c}$ & $12.64^{a}$ \\
\hline & $\mathrm{Si}+\mathrm{CCC}$ & $62.02^{\mathrm{d}}$ & $80.36^{a}$ & $80.43^{b}$ & $16.32^{\mathrm{b}}$ & $63.96^{d}$ & $80.12^{a}$ & $3.10^{c}$ & $4.71^{\mathrm{a}}$ & $9.36^{c}$ & $13.00^{\mathrm{b}}$ \\
\hline
\end{tabular}

For each parameter, means followed by the same letter are not significantly different at $\mathrm{P}=0.05$.

under water-limited conditions. Application of Si and CCC improved the soluble protein levels of water-stressed plants of both cultivars compared with plants exposed to drought stress without Si and CCC application, and the effect of $\mathrm{Si}+\mathrm{CCC}$ on soluble protein content was greater than of Si or CCC applied separately. Foliar application of Si + CCC also significantly increased soluble protein content by $6.96 \%$ and $17.61 \%$, respectively in cv. Gascogen and cv. Aflak under nonstress conditions (Table 2).

Concentrations of $\mathrm{K}, \mathrm{Mg}$ and $\mathrm{Ca}$ increased significantly under water stress, by $38.06 \%, 76.19 \%$ and $62.20 \%$, respectively, in cv. Aflak, and $15.62 \%, 25.21 \%$ and $12.36 \%$ in cv. Gascogen (Table 2). Drought-stressed plants fed with $\mathrm{Si}$ and CCC accumulated a greater concentration of $\mathrm{K}$ than control plants. Supplementation with CCC and $\mathrm{Si}+$ CCC caused a marked increase in Mg concentration in water-stressed plants compared with those receiving no foliar treatment (Table 2). Calcium concentration increased significantly in both cultivars under water stress; foliar application of Si, CCC and $\mathrm{Si}+\mathrm{CCC}$ caused a further increase in this nutrient only in $\mathrm{cv}$. Aflak. The concentrations of the three mineral nutrients $\mathrm{K}, \mathrm{Mg}$ and $\mathrm{Ca}$ were greater in cv. Aflak than in cv. Gascogen under water stress conditions (Table 2).

\section{Antioxidant enzyme activities, $\mathrm{H}_{2} \mathrm{O}_{2}$ and MDA}

The activity of POD was significantly increased due to water stress, by $75.06 \%$ in cv. Aflak and $5.49 \%$ in cv. Gascogen. In both cultivars, application of $\mathrm{Si}, \mathrm{CCC}$ and $\mathrm{Si}+\mathrm{CCC}$ significantly increased POD activity of water-stressed plants; the influence of Si + CCC was greater than of Si or CCC applied separately. POD was much higher in cv. Aflak than in cv. Gascogen under water-stress conditions, especially with foliar-applied $\mathrm{Si}+\mathrm{CCC}$ (Table 3 ).

Activity of SOD rose significantly under water-stress conditions, by $34.61 \%$ in $\mathrm{cv}$. Gascogen and $62.50 \%$ in cv. Aflak. Plants treated with $\mathrm{Si}$ or CCC had greater SOD activity than those grown solely under water limitation. The effect of $\mathrm{Si}+\mathrm{CCC}$ was greater than of $\mathrm{Si}$ or CCC applied separately. Varietal response to Si and CCC varied significantly for SOD activity; cv. Aflak was more responsive. In addition, under normal water conditions, combined application of $\mathrm{Si}+$ CCC significantly promoted SOD activity relative to no foliar application in both wheat varieties (Table 3).

Activity of APX also increased in both wheat varieties under water stress, and this increase was more pronounced in cv. Aflak. Application of Si and/or CCC had no significant effect on APX activity in cv. Gascogen under either water regime, whereas in cv. Aflak, APX significantly increased with application of CCC and Si + CCC under normal water conditions and with application of Si, CCC and $\mathrm{Si}+\mathrm{CCC}$ under water stress (Table 3 ).

In both cultivars, water stress increased the CAT activity. Application of Si or CCC supplementation had no significant effect on CAT activity in cv. Gascogen under either water-limited and 
Table 3: Influence of separate or combined application of Silicon ( $\left.\mathrm{Si}, 3.6 \mathrm{gL}^{-1}\right)$ and Cycocel (CCC, 210mgL $\left.\mathrm{L}^{-1}\right)$ on activities of Peroxidase (POD), Superoxide Dismutase (SOD), Ascorbate Peroxidase (APX) and Catalase (CAT), as well as levels of Hydrogen Peroxide $\left(\mathrm{H}_{2} \mathrm{O}_{2}\right)$ and Malondialdehyde (MDA) of two wheat cultivars (Gascogen and Aflak) under field water-stress and non-stress conditions.

\begin{tabular}{|c|c|c|c|c|c|c|c|c|c|c|c|c|c|}
\hline \multirow{2}{*}{$\begin{array}{l}\text { Irrigation } \\
\text { treatment }\end{array}$} & \multirow{2}{*}{$\begin{array}{l}\text { Chemical } \\
\text { treatment }\end{array}$} & \multicolumn{2}{|c|}{$\begin{array}{c}\text { POD } \\
\text { (Um g } \text { g }^{-1} \text { protein) }\end{array}$} & \multicolumn{2}{|c|}{$\begin{array}{c}\text { SOD } \\
\text { (Um g } \text { g }^{-1} \text { protein) }\end{array}$} & \multicolumn{2}{|c|}{$\begin{array}{c}\text { APX } \\
\text { (Um g } \text { g }^{-1} \text { protein) }\end{array}$} & \multicolumn{2}{|c|}{$\begin{array}{c}\text { CAT } \\
\text { (Um g } \text { g }^{-1} \text { protein) }\end{array}$} & \multicolumn{2}{|c|}{$\begin{array}{c}\mathrm{H}_{2} \mathrm{O}_{2} \\
\left(\mathrm{nmol} \mathrm{g}^{-1} \mathrm{FW}\right)\end{array}$} & \multicolumn{2}{|c|}{$\begin{array}{c}\text { MDA } \\
\left(\mathrm{mmol} \mathrm{g}{ }^{-1} \mathrm{FW}\right)\end{array}$} \\
\hline & & Gascogen & Aflak & Gascogen & Aflak & Gascogen & Aflak & Gascogen & Aflak & Gascogen & Aflak & Gascogen & Aflak \\
\hline \multirow{4}{*}{$100 \%$ FC } & 0 & $25.68^{f}$ & $38.02^{d}$ & $5.20^{f}$ & $5.12^{a}$ & $1.65^{\mathrm{ef}}$ & $1.18^{g}$ & $3.15^{\mathrm{gh}}$ & $3.12^{\mathrm{gh}}$ & $11.71^{\mathrm{g}}$ & $11.23^{9}$ & $5.42^{\mathrm{g}}$ & $5.54^{\mathrm{g}}$ \\
\hline & $\mathrm{Si}$ & $24.36^{f}$ & $40.32^{d}$ & $5.18^{f}$ & $5.15^{b}$ & $1.64^{\mathrm{ef}}$ & $1.22^{\mathrm{g}}$ & $3.16^{g h}$ & $3.10^{g h}$ & $11.02^{\mathrm{g}}$ & $11.00^{\mathrm{g}}$ & $4.00^{\mathrm{h}}$ & $4.14^{\mathrm{gh}}$ \\
\hline & $\mathrm{CCC}$ & $24.52^{f}$ & $37.25^{d}$ & $6.00^{\mathrm{e}}$ & $5.97^{a}$ & $1.75^{\mathrm{e}}$ & $1.86^{e}$ & $3.15^{\mathrm{gh}}$ & $3.13^{g h}$ & $11.00^{\mathrm{g}}$ & $11.12^{\mathrm{g}}$ & $3.47^{\mathrm{h}}$ & $3.23^{h}$ \\
\hline & $\mathrm{Si}+\mathrm{CCC}$ & $25.48^{f}$ & $40.98^{d}$ & $6.50^{\text {de }}$ & $6.02^{b}$ & $1.77^{\mathrm{e}}$ & $1.83^{e}$ & $3.57^{\mathrm{g}}$ & $3.89^{9}$ & $10.81^{g}$ & $10.00^{g}$ & $3.20^{\mathrm{h}}$ & $3.14^{\mathrm{h}}$ \\
\hline \multirow{4}{*}{$40 \% \mathrm{FC}$} & 0 & $27.09^{\text {ef }}$ & $66.56^{c}$ & $7.00^{d}$ & $8.32^{a}$ & $2.24^{\text {cd }}$ & $2.87^{c}$ & $5.11^{\text {ef }}$ & $7.21^{\mathrm{cd}}$ & $56.62^{a}$ & $42.71^{a}$ & $17.20^{\mathrm{a}}$ & $12.36^{c}$ \\
\hline & $\mathrm{Si}$ & $30.36^{e}$ & $76.32^{\mathrm{ab}}$ & $7.50^{\text {cd }}$ & $9.12^{\mathrm{a}}$ & $3.85^{c}$ & $3.62^{\mathrm{ab}}$ & $5.41^{\mathrm{e}}$ & $7.84^{c}$ & $38.01^{c}$ & $22.23^{e}$ & $14.35^{\mathrm{b}}$ & $9.23^{e}$ \\
\hline & $\mathrm{CCC}$ & $29.39^{e}$ & $71.65^{b}$ & $7.50^{\text {cd }}$ & $9.32^{a}$ & $3.92^{c}$ & $3.88^{a}$ & $5.55^{e}$ & $8.02^{b}$ & $33.58^{d}$ & $25.34^{\mathrm{e}}$ & $11.63^{c}$ & $6.32^{\mathrm{f}}$ \\
\hline & $\mathrm{Si}+\mathrm{CCC}$ & $33.87^{e}$ & $82.36^{a}$ & $8.01^{d}$ & $10.54^{b}$ & $3.87^{c}$ & $3.86^{a}$ & $5.84^{e}$ & $8.87^{a}$ & $28.78^{e}$ & $15.34^{f}$ & $11.23^{\text {cd }}$ & $6.42^{f}$ \\
\hline
\end{tabular}

For each parameter, means followed by the same letter are not significantly different at $\mathrm{P}=0.05$.

Table 4: Influence of separate or combined application of Silicon (Si, 3.6 $\left.\mathrm{gL}^{-1}\right)$ and Cycocel (CCC, 210mgL $\left.\mathrm{L}^{-1}\right)$ on relative water content and leaf water potential of two wheat cultivars (Gascogen and Aflak) under field water-stress and non-stress conditions.

\begin{tabular}{|c|c|c|c|c|c|}
\hline \multirow{2}{*}{ Irrigation treatment } & \multirow{2}{*}{ Chemical treatment } & \multicolumn{2}{|c|}{ Relative water content (\%) } & \multicolumn{2}{|c|}{ Leaf water potential (-MPa) } \\
\hline & & Gascogen & Aflak & Gascogen & Aflak \\
\hline \multirow{4}{*}{$100 \%$ field capacity } & 0 & $82.32^{b}$ & $83.01^{b}$ & $1.79^{\mathrm{e}}$ & $32.80^{\mathrm{e}}$ \\
\hline & $\mathrm{Si}$ & $82.21^{\mathrm{b}}$ & $84.09^{b}$ & $1.78^{\mathrm{e}}$ & $29.78^{e}$ \\
\hline & $\mathrm{CCC}$ & $82.00^{\mathrm{b}}$ & $84.10^{\mathrm{b}}$ & $1.75^{\mathrm{e}}$ & $33.78^{e}$ \\
\hline & $\mathrm{Si}+\mathrm{CCC}$ & $82.00^{b}$ & $84.00^{\mathrm{b}}$ & $1.73^{\mathrm{e}}$ & $21.68^{\mathrm{ef}}$ \\
\hline \multirow{4}{*}{$40 \%$ field capacity } & 0 & $40.13^{f}$ & $57.02^{\mathrm{c}}$ & $2.99^{a}$ & $32.43^{\text {bc }}$ \\
\hline & $\mathrm{Si}$ & $45.15^{\mathrm{e}}$ & $82.32^{\mathrm{b}}$ & $2.50^{b}$ & $30.96^{d}$ \\
\hline & $\mathrm{CCC}$ & $45.20^{e}$ & $82.23^{b}$ & $2.51^{b}$ & $32.97^{d}$ \\
\hline & $\mathrm{Si}+\mathrm{CCC}$ & $49.40^{d}$ & $88.20^{\mathrm{a}}$ & $2.21^{\mathrm{c}}$ & $29.85^{d}$ \\
\hline
\end{tabular}

For each parameter, means followed by the same letter are not significantly different at $\mathrm{P}=0.05$.

normal watering conditions, whereas in cv. Aflak, CAT activity increased with application of CCC and Si + CCC under droughtstress conditions (Table 3).

Levels of $\mathrm{H}_{2} \mathrm{O}_{2}$ increased markedly under water-limited conditions. Plants treated with $\mathrm{Si}$ and/or CCC had lower $\mathrm{H}_{2} \mathrm{O}_{2}$ levels than plants under water stress alone. Furthermore, the influence of $\mathrm{Si}$ $+\mathrm{CCC}$ application on $\mathrm{H}_{2} \mathrm{O}_{2}$ content was greater than with either $\mathrm{Si}$ or CCC applied separately. With application of Si, CCC and Si + CCC and under water stress, $\mathrm{H}_{2} \mathrm{O}_{2}$ content was lower than with no foliar application, in both cultivars (Table 3 ).

In addition, drought stress caused a significant increase in the levels of MDA in both wheat cultivars. Although the cultivars did not differ significantly from each other under normal watering, $\mathrm{cv}$. Gascogen (drought-sensitive) had considerably higher levels of MDA than cv. Aflak (drought-tolerant) under water-limited conditions. Treatment with $\mathrm{Si}, \mathrm{CCC}$ and $\mathrm{Si}+\mathrm{CCC}$ decreased MDA levels under both non-stress and water-limited regimes in both cultivars, but the influence was more evident under water deficit (Table 3).

\section{Relative water content and leaf water potential ( $\Psi \mathrm{m})$}

Water-deficit treatments caused a marked suppression in RWC and $\Psi \mathrm{m}$ in both wheat varieties. However, cv. Aflak had higher RWC and $\Psi \mathrm{m}$ than $\mathrm{cv}$. Gascogen under drought stress. Application of $\mathrm{Si}$, CCC and Si + CCC significantly improved the RWC and $\Psi \mathrm{m}$ of water-stressed plants in both cultivars (Table 4).

\section{Discussion}

Water-deficit stress (40\% FC) causes reduction of duration of anthesis to grain-ripening stage, and consequently the yield of two wheat cultivars in the present study. Indeed, the importance of water presence during grain filling for yield formation of bread wheat was shown here. As a whole, Water-deficit during anthesis and grain filling reduces weight and number of grains [3-5]. Impaired grain filling was reported to be attributable to reduced partitioning of assimilates and reduced activities of key enzymes involved in sucrose and starch synthesis [5]. However, reduction of grain yield, yield components and biological yield in both wheat cultivars was lower in the presence of externally applied $\mathrm{Si}$, CCC, and especially combined $\mathrm{Si}+$ CCC. Therefore, application of $\mathrm{Si}$ and CCC could improve grain yield under water-stress conditions. Similarly, Tahir et al. [41] observed that exogenous application of Si promoted grain yield in a wheat crop (by $50 \%$ ) under stressful environmental conditions. Researchers (e.g. $[7,10,12]$ have reported observation of a significant improvement in biomass under water-deficit stress, showing a promising effect of exogenous application of $\mathrm{Si}$ in compensating the harmful effects of water-deficit. Sonobe et al. [28]; Ahmed et al. [42] showed that these results are the same as reports for sorghum (Sorghum bicolor). Moreover, foliar implementation of CCC was reported to cause a considerable raise in yield of wheat under water-stress conditions $[43,44]$.

Water-deficit stress conditions are considered to influence 
physiological responses and growth of several cereal crops $[45,46]$, and several researches state that $\mathrm{Si}$ could improve tolerance of plants under stressful circumstances [47-50].

Si-induced growth promotion under water-starved regimes has been reported in different crops, e.g. wheat [10,51,52], rice (Oryza sativa) [50,53] and soybean (Glycine max) [54].

Silicon is indispensable for promoting growth of several crops including cereals [55], and CCC, like several other known plant growth regulators, plays a key role in promoting plant resistance against drought stress [19]. Some reports show the vital role of exogenous supply of CCC in counteracting injurious effects of stressful environments in different plants [18]. Both CCC, as a plant growth regulator, and $\mathrm{Si}$, as a mineral, are believed to regulate different physio-biochemical processes in plants including photosynthesis, stomatal regulation and ion uptake. Therefore, Si and CCC have potential functions in initiating plant growth and productivity $[18,31,50,56]$

Implementation of Si can considerably alleviate water-deficit damage in various plants $[12,42,50,51,55-58]$. Several researchers reported the advantages of soil-applied $\mathrm{Si}$ in counteracting both abiotic and biotic stresses [8,51,57]; while, few studies have investigated the useful effects of foliar-applied Si for counteracting these stresses $[59,60]$.

The present investigation showed that increased activity of antioxidant enzymes such as CAT, POD, APX and SOD occurred to alleviate water-stress-induced adverse effects on wheat plants. Similar findings have been reported by Tari et al. [61] and Ashraf [14]. Molassiotis et al. [62] found that ROS-induced oxidative damage may cause oxidation of lipids and proteins. However, in the view of Moller et al. [63], a balance between ROS generation and the activities of antioxidant enzymes may ensure the extent to which oxidative damage and signaling will take place. In fact, capacity to scavenge ROS may promote drought tolerance in plants [64].

In this study, Implementation of CCC and Si raised the activity of some key enzymes taking part in the oxidative defenses system and declined the levels of MDA and $\mathrm{H}_{2} \mathrm{O}_{2}$ in drought-stressed plants. Furthermore, in cv. Aflak, the synergistic effects of Si + CCC on activity of antioxidant enzymes were greater than effects of CCC or Si applied separately, under drought-stress conditions.

Our results are similar to findings reported by other workers demonstrating that $\mathrm{Si}$ application to soil is very effective in mitigating the harmful effects of environmental stresses including drought $[7,8,12,31]$. A similar mechanism of Si and CCC in reducing drought stress is the improvement of antioxidant activity in plants under abiotic stresses $[13,25]$. Our findings also show that exogenously applied Si [15] and CCC [26,65] modulate the activities of vital antioxidant enzymes such as SOD and POD, and improve plant tolerance to drought stress.

A raise in mineral nutrient ions $\left(\mathrm{K}^{+}, \mathrm{Mg}^{2+}, \mathrm{Ca}^{2+}\right.$ and $\left.\mathrm{Na}^{+}\right)$is considered another critical mechanism for plants to endure the stress [66]. In the present study, piling up of $\mathrm{K}^{+}, \mathrm{Ca}^{2+}$ and $\mathrm{Mg}^{2+}$ occurs in the leaves of plants under water-deficit conditions, and foliar-applied $\mathrm{Si}$, the same as CCC, resulted in a further increase in $\mathrm{K}^{+}$levels in the leaves of water-stressed wheat plants.

Soluble sugars also generally increase in plant tissues exposed to water-limited conditions and they are potential contributors to osmoregulation [67]. In our study, soluble sugars (as osmolytes) were considerably enhanced in the wheat leaves exposed to low water supply, more markedly in cv. Aflak (drought-tolerant), than in cv. Gascogen. Foliar application of CCC and Si further increased soluble sugar content and in cv. Aflak, and the synergistic effect of Si + CCC application was greater than of Si or CCC alone. Enhanced levels of soluble sugars are believed to have a role in stress tolerance, because soluble sugars are actively involved in protection of enzyme structure, osmoregulation, biological membrane stabilization and protection against hydroxyl radicals [67]. Nayyar and Walia [68] found that stress-resistant plants usually accumulate greater amounts of soluble sugars than stress-sensitive plants.

Leaf water potential is a potential indicator for determining plant water status, and it plays a key role in enhancing plant photosynthetic rate [69]. In the present investigation, drought-tolerant cv. Aflak maintained significantly higher $\Psi \mathrm{m}$ and RWC than drought-sensitive cv. Gascogen under water-limited conditions.

Zhu et al. [70] showed that Si significantly improves the water conditions of plant leaves, which helps the plant to alleviate cellular dehydration, and therefore lower oxidative stress. Furthermore, Gong et al. [24,51] showed that application of Si to soil can improve leaf $\Psi \mathrm{m}$ in plants under water-deficit conditions. Si-induced improvement in $\Psi \mathrm{m}$ may be related to raise stomatal conductance and higher relative water content.

Thus, Si plays an effective role in maintaining water balance in plant tissues, most probably through higher water uptake. Isa et al. [27] reported that Si supply may improve the rigidity and strength of cell walls, thereby helping to reduce the solute leakage and stabilize the ultrastructure of biological membranes.

Silicon deposition in the cytoplasm of cells is a unique mechanism of $\mathrm{Si}$ in reducing abiotic stress in plants. Nonetheless, the functions of $\mathrm{Si}$ and CCC in water uptake and osmoregulation in plants under drought are not yet well defined. The results of this research show that osmolyte accumulation in leaves of plants treated with Si and CCC under drought stress was more prominent in drought-stressed plants receiving no Si or CCC treatment. Therefore, application of Si [7] and CCC [18] can improve the ability of plants to regulate themselves osmotically to keep high water content and leaf water potential.

\section{Conclusion}

Foliar application of Si, CCC and especially the combination $\mathrm{Si}+$ CCC, markedly improved grain yield and yield components of the two wheat cultivars under water-deficit. In $\mathrm{Si}, \mathrm{CCC}$ and $\mathrm{Si}+$ CCC treatments, grain yield was $15.63 \%, 16.60 \%$ and $24.32 \%$ higher respectively, than with no foliar application under water stress in cv. Aflak, and 10.25\%, 16.02\% and 19.25\% higher in cv. Gascogen The results of the study highlight the role of Si and CCC application in regulating water-stress response of wheat, suggesting that $\mathrm{Si}$ and CCC are involved in physiological activities. These results showed positive effects of $\mathrm{Si}$ and CCC in terms of increased antioxidant activity as well as relative water content and leaf water potential. In 
addition, Si and CCC stimulated the active accumulation of some osmolytes in leaves of water-stressed wheat plants, which suggests enhanced osmoregulation ability. The synergistic effects of Si + CCC application on yield and physiological parameters were greater than of Si or CCC applied separately. Therefore, proper application of Si and CCC might result in increased production of wheat, particularly in dryland areas.

\section{References}

1. Curtis T, Halford NG. Food security: the challenge of increasing wheat yield and the importance of not compromising food Safety. Ann Appl Biol. 2014; 164: 354-372.

2. González A, Bermejo V, Gimeno BS. Effect of different physiological traits on grain yield in barley grown under irrigated and terminal water deficit conditions. The J. Agri. Sci. 2010; 148: 319-328.

3. Thapa S, Reddy SK, Fuentealba MP, Xue Q, Rudd JC, Jessup KE, et al. Physiological responses to water stress and yield of winter wheat cultivars differing in drought tolerance. J Agro Crop Sci. 2018; 204: 347-358.

4. Erocli L, Lulli L, Mariotti M, Masoni A, Arduini I. Postanthesis dry matter and nitrogen dynamics in durum wheat. Crop Sci. 2007; 34: 1443-1451.

5. Sinclair TR. Challenges in breeding for yield increase for drought. Trend. Plant Sci. 2011; 16: 289-293.

6. Rao GB, Pi PY, Syriac EK. Effect of various silicon sources on nutrient uptake by rice and available nutrient status in soil. J Pharm. Phytochem. 2018; 7 : 1449-1452.

7. Zhang W, Xie Z, Wang L, Li M, Lang D, Zhang X. Silicon alleviates salt and drought stress of Glycyrrhiza uralensis seedling by altering antioxidan metabolism and osmotic adjustment. J Plant Res. 2017; 130: 611-624.

8. Li QF, Ma CC, Ji J. Effect of silicon on water metabolism in maize plants under drought stress. Acta Ecol. Sin. 2009; 29: 4163-4168.

9. Javaid T, Farooq MA, Akhtar J, Saqib ZA. Silicon nutrition improves growth of salt-stressed wheat by modulating flows and partitioning of $\mathrm{Na}^{+}, \mathrm{Cl}^{-}$and mineral ions. Plant Physiol. Bioch. 2019; 141: 291-299.

10. Maghsoudi K, Emam Y, Ashraf M. Foliar application of silicon at differen growth stages alters growth and yield of selected wheat cultivars. J Plant Nut. 2016; 39: 1194-1203.

11. Haddad C, Arkoun M, Jamois F, Schawarzbenberg A, Yvin JC, Etienne P, et al. Silicon promotes growth of Brassica napus $L$. And delays leaf senescence induced by nitrogen starvation. Fron Plant Sci. 2018; 9: 516.

12. Parveen $\mathrm{N}$, Ashraf $\mathrm{M}$. Role of silicon in mitigating the adverse effects of salt stress on growth and photosynthetic attributes of two maize (Zea mays L.) cultivars grown hydroponically. Pakist J Bot. 2010; 42: 1675-1684.

13. Liang YC, Sun WC, Zhu YG. Mechanisms of silicon-mediated alleviation of abiotic stresses in higher plants: a review. Environ Poll. 2007; 147: 422-428.

14. Ashraf M. Biotechnological approach of improving plant salt tolerance using antioxidants as markers. Biotech. Advanc. 2009; 27: 84-93.

15. Sedaghat M, Tahmasebi Sarvestani Z, Emam Y, Mokhtassi Bidgoli A. Photosynthetic rate, growth and yield of mustard plants sprayed with 28 homobrassinolide. Plant Physiol. Biochem. 2017; 119: 59-69.

16. Tuna AL, Kaya C, Dilkilitas M, Yokas I, Buruni B, Altunlu H. Comparative effects of various Cycocel derivatives on key growth parameters and some enzyme activities in salinity stressed maize (Zea mays L.) plants. Pakist. J. Bot. 2007; 39: 787-798

17. Arora N, Bhardwaj R, Sharma P, Arora HK. 28-Homobrassinolide alleviates oxidative stress in slt treated maize (Zea mays L.) plants. Brazil. J Plant Physiol. 2008; 20: 153-157.

18. Hayat Q, Hayat S, Irfan M, Ahmad A. Effect of exogenous Cycocel under changing environment. A review. Environ. Exper. Bot. 2010; 68: 14-25.

19. Ashraf M, Foolad MR. Roles of glycine betaine and proline in improving plant abiotic stress resistance. Environ. Experim. Bot. 2007; 59: 206-216.

20. Kaydan D, Yagmur M, Okut N. Effects of Cycocel on the growth and some physiological characters in salt stressed wheat (Triticum aestivum L.). Tarim Bilimleri Dergisi. 2007; 13: 114-119.

21. Morris K, MacKerness Sa, Page T, John CF, Murphy AM, Carr JP, et al. Cycocel has a role in regulating gene expression during leaf senescence. The Plant J. 2000; 23: 677-685.

22. Khan W, Prithiviraj B, Smith D. Photosynthetic responses of corn and soybean to foliar application of salicylates. J Plant Physiol. 2003; 160: 485-492.

23. Misra N, Saxena P. Effect of Cycocel on proline metabolism in lentil grown under salinity stress. Plant Sci. 2009; 177: 181-189.

24. Gong HJ, Chen KM, Zhao ZG, Chen GC, Zhou WJ. Effects of silicon on defense of wheat against oxidative stress under drought at different developmental stages. Biol Planta. 2008; 52: 592-596.

25. Senaratna T, Touchell D, Bunn E, Dixon K. Acetyl Cycocel (Aspirin) and Cycocel induce multiple stress tolerance in bean and tomato plants. Plan Gro. Reg. 2000; 30: 157-161.

26. Khodary SEA. Effect of Cycocel on growth, photosynthesis and carbohydrate metabolism in salt-stressed maize plants. Inter. J Agri Biol. 2004; 6: 5-8.

27. Isa M, Bai S, Yokoyama T, Ma JF, Ishibashi Y, Yuasa T, et al. Silicon enhances growth independent of silica deposition in a low-silica rice mutant. Plant Soil. 2010; 331: 361-375.

28. Sonobe K, Hattori T, An P, Tsuji W, Eneji AE, Kobayashi S, et al. Effect of silicon application on sorghum root responses to water stress. J Plant Nut. 2010; 34: 71-82.

29. Murmu K, Murmu S, Kundu CK, Bera PS. Exogenous proline and glycine betaine in plants under stress tolerance. Inter. J Cur Micro Appl Sci. 2017; 6: 901-913.

30. Szabados L, Savoure A. Proline: a multifunctional amino acid. Trends Plant Sci. 2010; 15: 89-97.

31. Ashraf M, Rahmatullah R, Ahmad M, Afzal M, Tahir A, Kanwal S, et al. Potassium and silicon improve yield and juice quality in sugarcane (Saccharum officinarum L.) under salt stress. J Agro Crop Sci. 2009; 195: 284-291.

32. Castillo FJ. Antioxidative protection in the inducible CAM plant Sedum album L. following the imposition of severe water stress and recovery. Oecologia. 1996; 107: 469-477.

33. Zhang ZJ, Li HZ, Zhou WJ, Takeuchi Y, Yoneyama K. Effect of 5-aminolevulinic acid on development and salt tolerance of potato (Solanum tuberosum L.) microtubers in vitro. Plant Gro Reg. 2006; 49: 27-34.

34. Bradford MM. A rapid and sensitive method for the quantitation of microgram quantities of protein utilizing the principle of protein-dye binding. Analytic Bioch. 1976; 72: 248-254

35. Cakmak I, Strbac D, Marschner H. Activities of hydrogen peroxide scavenging enzymes in germinating wheat seeds. J Experim Bot. 1993; 44: 127-132.

36. Nakano Y, Asada K. Hydrogen peroxide is scavenged by ascorbate specific peroxidase in spinach chloroplasts. Plant. Cell Physiol. 1981; 22: 867-880.

37. Aebi H. Catalase in vitro. Methods in enzymology. 1984; 105: 121-126.

38. Dhindsa RS, Matow W. Drought tolerance in two mosses: correlated with enzymatic defense against lipid peroxidation. J. Experi. Bot. 1981; 32: 79-91.

39. Veljovic-Jovanovic S, Noctor G, Foyer $\mathrm{CH}$. Are leaf hydrogen peroxide concentrations commonly overestimated? The potential influence of art factual interference by tissue phenolics and ascorbate. Plant Physiol. Biochem. 2002; 40: 501-507.

40. Hodges DM, De Lond JM, Forney CF, Prange RK. Improving the thiobarbituric acid-reactive substances assay for estimating lipid peroxidation in plant tissues containing anthocyanin and other interfering compounds. Planta. 1999; 207: 604-611.

41. Tahir MA, Tullah R, Aziz T, Ashraf M, Kanwal S, Maqsood MA. Beneficia 
effects of silicon in wheat (Triticum aestivum L.) under salinity stress. Pakist J Bot. 2006; 38: 1715-1722.

42. Ahmed M, Hassen FU, Qadeer U, Aslam MA. Silicon application and drought tolerance mechanism of sorghum. Afric. J Agri Res. 2011; 6: 594-607.

43. Ahmad I, Basra SMA, Wahid A. Exogenous application of ascorbic acid, Cycocel and hydrogen peroxide improves the productivity of hybrid maize at low temperature stress. Inter. J Agri Biol Sci. 2014; 16: 825-830.

44. Zamaninejad M, Khorasani SK, Moeini MJ, Heidarian AR. Effect of Cycoce on morphological characteristics, yield and yield components of corn (Zea mays L.) under drought condition. Europ J Experim Biol. 2013; 3: 153-161.

45. Maghsoudi K, Maghsoudi Moud AA. Analysis of the effects of stomata frequency and size on transpiration and yield of wheat (Triticum aestivum L.). American-Euras J Agri Environ Sci. 2008; 3: 865-872.

46. Yao XQ, Chu JZ, Wang GY. Effects of drought stress and selenium supply on growth and physiological characteristics of wheat seedlings. Acta Physiol Plantar. 2009; 5: 1031-1036.

47. Hattori $\mathrm{T}$, Sonobe $\mathrm{K}$, Inanaga S. Short term stomata responses to light intensity changes and osmotic stress in sorghum seedlings raised with and without silicon. Environ Experiment Bot. 2007; 60: 177-182.

48. Liang Y, Zhu J, Li Z, Chu G, Ding Y, Zhang J, et al. Role of Si in enhancing resistance to freezing stress in two contrasting winter wheat cultivars. Environ Experi Bot. 2008; 64: 286-294.

49. Maghsoudi K, Emam Y, Ashraf M. Influence of foliar application of silicon on chlorophyll fluorescence, photosynthetic pigments, and growth in waterstressed wheat cultivars differing in drought tolerance. Turk J Bot. 2015; 39: $625-634$

50. Mauad M, Cruscio CAC, Nascente AS, Filho HG, Lima GPP. Effects of silicon and drought stress on biochemical characteristics of leaves of upland rice cultivars. Ciência Agro. 2016; 47: 532-539.

51. Gong H, Zhu X, Chen K, Wang S, Zhang C. Silicon alleviates oxidative damage of wheat plants in pots under drought. Plant Sci. 2005; 169: 313-321.

52. Gong $\mathrm{H}$, Chen $\mathrm{K}$. The regulatory role of $\mathrm{Si}$ on water relations, photosynthetic gas exchange, and carboxylation activities of wheat leaves in field drought conditions. Acta Physiol Planta. 2012; 34: 1589-1594.

53. Chen W, Yao X, Cai K, Chen J. Silicon alleviates drought stress of rice plants by improving plant water status, photosynthesis and mineral nutrient absorption. Biol. Trace Element Res. 2011; 142: 67-76.

54. Shen X, Zhou Y, Duan L, Li Z, Eneji AE, Li J. Si effects on photosynthesis and antioxidant parameters of soybean seedlings under drought and ultraviolet-B radiation. J Plant Physiol. 2010; 167: 1248-1252.

55. Broadley M, Brown P, Cakmak I, Ma JF, Rengel Z, Zhao F. Beneficial elements. In marschners mineral nutrition of higher plants. $3^{\text {rd }}$ edn (Ed. P Marschner) (Academic Press: London, UK). 2012.
56. Ali EF, Hassan FAS. Water stress alleviation of Roselle plant by silicon treatment through some physiological and biochemical responses. Annual Res Rev Biol. 2017; 21: 1-17.

57. Hattori T, Inanagaa S, Arakib H. Application of silicon enhanced drought tolerance in Sorghum bicolor. Physiol Plant. 2005; 123: 459-466.

58. Cooke J, Leishman MR. Is plant ecology more siliceous than we realise? Trends Plant Sci. 2011; 16: 61-68.

59. Guével MH, Menzies, JG, Belanger RR. Effect of root and foliar applications of soluble silicon on powdery mildew control and growth of wheat plants. Europ J Plant Pathol. 2007; 119: 429-436.

60. Hellal FA, Abdelhameid M, Abo-Basha Doaa M, Zewainy RM. Alleviation of the adverse effects of soil slinity stress by foliar application of silicon on faba bean (Vica faba L.). J Appl Sci Res. 2012; 8: 4428-4433.

61. Tari I, Simon LM, Deer KA, Csiszar J, Bajkan S, Kis G, et al. Influence of Cycocel on salt stress acclimation of tomato plants: oxidative stress responses and osmotic adaptation. Acta Physiol Planta. 2004; 26: 230-237.

62. Molassiotis A, Sotiropoulos T, Tanou G, Diamantidis G, Therios I. Boroninduced oxidative damage and antioxidant and nucleolytic responses in shoot tips culture of the apple rootstock EM9 (Malus domestica Borkh). Environ Expire Bot. 2006; 56: 54-62.

63. Moller M, Jensen PE, Hansson A. Oxidative modifications to cellula components in plants. Ann. Rev. Plant Bio. 2007; 58: 459-481.

64. Tsugane K, Kobayashi K, Niwa Y, Ohba Y, Wada K, Kobayashi H. A recessive Arabidopsis mutant that grows photoautotrophically under salt stress shows enhanced active oxygen detoxification. The Plant Cell. 1999; 11: 1195-1206.

65. Shakirova FM. Role of hormonal system in the manifestation of growth promoting and anti-stress action of Cycocel. In 'Cycocel, a plant hormone. (Eds S Hayat, A Ahmad) (Springer: Dordrecht, The Netherlands). 2007.

66. Zhu X, Gong H, Chen G, Wang S, Zhang C. Different solute levels in two spring wheat cultivars induced by progressive field water stress at different developmental stages. J Arid Environ. 2005; 62: 1-14

67. Shao HB, Liang ZS, Shao MA. Osmotic regulation of 10 wheat (Triticum aestivum L.) genotypes at soil water deficits. Colloids and Surfaces. B, Biointerfaces. 2006; 47: 132-139.

68. Nayyar H, Walia DP. Water stress induced proline accumulation in contrasting wheat genotypes as affected by calcium and abscisic acid. Biol Plant. 2003; 46: $275-279$.

69. Endres L, Silva JV, Ferreira VM, Ver G, Barbosa DS. Photosynthesis and water relations in Brazilian sugarcane. The Open Agr. J. 2010; 4: 31-37.

70. Zhu Z, Wei G, Li J, Qian Q, Yu J. Silicon alleviates salt stress and increases antioxidant enzymes activity in leaves of salt-stressed cucumber (Cucumis Sativus L.). Plant Sci. 2004; 167: 527-533. 